\title{
Pengaruh Ekstrak Alpinia galanga L Terhadap Produksi Biofilm pada Escherichia coli
}

\section{Effect of Alpinia galanga L Extract on Biofilm Production in Escherichia coli}

\author{
Didik Wahyudi ${ }^{1}$, Syahran Wael ${ }^{2}$ \\ didikww@gmail.com \\ ${ }^{1}$ Program Studi Teknologi Laboratorium Medis, Sekolah Tinggi Ilmu Kesehatan Nasional, Surakarta \\ 2Program Studi Pendidikan Biologi, Universitas Pattimura, Maluku. \\ Riwayat Artikel: Dikirim Desember 2020; Diterima Februari 2021; Diterbitkan Maret 2021
}

\begin{abstract}
Abstrak
Escherichia coli merupakan bakteri Gram negatif berbentuk batang, mampu menyebabkan infeksi di beberapa bagian tubuh, dan ditemukan telah resisten terhadap berbagai antibiotic, salah satu factor penyebabnya adalah kemampuannya membentuk biofilm pada jaringan. Alpinia gallanga L memiliki kemampuan menghambat pembentukan biofilm terhadap beberapa bakteri. Tujuan Penelitian ini adalah untuk mengetahui kemampuan ekstrak Alpinia galangal L dalam menghambat produksi biofilm Escherichia coli. Penelitian ini di awali dengan ekstraksi rimpang lengkuas dengan etanol menggunakan metode masersi, kemudian dibuat konsentrasi $10 \%, 20 \%, 30 \%, 40 \%$, dan 50\%. Escherichia coli diisolasi dari kasus Infeksi Saluran Kemih (ISK). kemudian di lakukan karakterisasi fisiologisnya dan uji kepekaan terhadap antibiotik. Uji penghambatan biofilm Escherichia coli dilakukan dengan metode microtiter plate culture dengan menggunakan spektrofotometer pada panjang gelombang $595 \mathrm{~nm}$, Hasil pengukuran produksi biofilm berupa besarnya nilai Optical Density crystal violet $0,1 \%$, setiap perlakuan menggunakan ulangan 8 kali, data yang didapatkan dianalisis dengan One Way Anova. Hasil Penelitian menunjukan bahwa Ekstrak Alpinia galanga L mampu menghambat produksi biofilm Escherichia coli pada konsentrasi 30\%.
\end{abstract}

Kata Kunci : Biofilm, Escherichia coli, Alpinia galanga L

\begin{abstract}
Escherichia coli is a Gram-negative rod-shaped bacteria, capable of causing infection in several parts of the body, and has been found to be resistant to various antibiotics, one of the contributing factors is its ability to form biofilms in tissues. Alpinia gallanga $L$ has the ability to inhibit biofilm formation against several bacteria. The purpose of this study was to determine the ability of Alpinia galangl L extract in inhibiting the production of Escherichia coli biofilm. This research began with the extraction of galangal rhizome with ethanol using the masersion method, then made the concentrations of $10 \%$, $20 \%, 30 \%, 40 \%$, and $50 \%$. Escherichia coli was isolated from cases of Urinary Tract Infection (UTI). then do the physiological characterization and sensitivity test to antibiotics. Inhibition test for Escherichia coli biofilm was carried out using the microtiter plate culture method using a spectrophotometer at a wavelength of $595 \mathrm{~nm}$. The measurement results of biofilm production were $0.1 \%$ Optical Density crystal violet value, each treatment used 8 replications, the data obtained were analyzed by One Way Anova. . The results showed that the extract of Alpinia galanga $L$ was able to inhibit the production of Escherichia coli biofilm at a concentration of $30 \%$.
\end{abstract}

Keywords : Biofilm, Escherichia coli, Alpinia galanga L 


\section{Pendahuluan}

Escherichia coli merupakan bakteri Gram negatif berbentuk, ditemukan mampu menyebabkan infeksi di beberapa bagian tubuh (Widianingsih \& de Jesu, 2018). E. coli telah ditemukan resisten terhadap berbagai antibiotik (Al-Shabib et al., 2017; Hilda, 2017); Moradigaravand et al., 2018; Sumampouw, 2018; Jihan, 2019). Hal ini akan menyulitkan pengobatan, sehingga proses penyembuhan menjadi lebih lama dan biaya pengobatan meningkat (Jihan, 2019; Widianingsih \& de Jesus, 2018). Ada beberapa faktor yang menyebabkan E. coli menjadi resisten terhadap berbagai antibiotik, mutasi spontan yang timbul akbibat mengkonsumsi antibiotic tidak sesuai dengan aturan (Widianingsih \& de Jesus, 2018), factor penyebab lain yang perlu dipertimbangkan adalah karena kemampuan $E$. coli dalam membentuk biofilm (Fajrin., 2020). Beberapa peneliti menemukan ada hubungan yang erat antara kemampuan membentuk biofilm dengan resistensi bakteri terhadap antibiotik (Wahyudi et al., 2019., Cepas et al., 2019; Viana et al., 2020).

Biofilm menyebabkan penetrasi antibiotik ke dalam sel bakteri terhambat (Abdelhamid et al., 2018), dan di dalam biofilm tersebut terjadi rekombinasi DNA bakteri sehingga tukar menukar gen pengendali resisten terhadap antibiotik bisa terjadi (Surgers et al., 2019; Wahyudi et al., 2019;). Beberapa ekstrak tanaman herbal telah ditemukan mampu menghambat pembentukan biofilm dan mencegah sistem quorum sensing (Wahyudi \& Silviani, 2015; Fajrin, 2020, Nadhiroh, 2019; Viana et al., 2020); salah satunya adalah Alpinia galangal $\mathrm{L}$ telah ditemukan mampu menghambat sistem quorum sensing pada beberapa bakteri patogen (Wahyudi et al., 2011; Rini et al., 2018; Prasetya et al., 2019), dan beberapa ekstrak herbal mampu menghambat pembentukan eksoprotease Salmonella typi, meskipun tidak mampu menghambat pertumbuhan sel, namun mampu menghambat produksi biofilm, dan sistem quorum sensing (produksi eksoprotease) (Wahyudi \& Silviani, 2015).

Alpinia galangal L memiliki senyawa golongan lakton yang memiliki struktur yang mrip dengan Acil homoserin lacton yang merupakan molekul sinyal di dalam sistem quorum sensing bakteri Gram negatif (Wahyudi et al., 2011; Nadiroh, 2019). Senyawa tersebut bekerja dengan sistem inhibitor competitive pada sistem quorum sensing, yang merupakan salah satu sietm pengendali pembentukan biofilm bakteri (Putri, 2019; Prasetya et al., 2019). Pembentukan biofilm pada E. coli secara dominan dikendalikan oleh sistem quorum sensing, yang dipengaruhi oleh faktor-faktor lingkungan (nutrisi, kimiawi, dan fisik), Alpini galangal L merupakan salah satu herbal yang berpotensi menghambat pembentukan biofilm pada E. coli. Tujaun penelitian ini adalah untuk mengetahui kemampuan Ekstrak Alpini galangal L dalam menghambat prodiuksi biofilm pada E. coli.

\section{Metode Penelitian}

\section{Alat}

Autoclave (Astel), inkubator (Heraeus), oven (Heraeus), microtiter plate, laminar air flow, waterbath; seperangkat alat untuk percobaan kultivasi: petridish, tabung reaksi, labu elenmeyer, beker glass; refrigerator (National), spektrofotometer (Shimadzu UV mini 1240), microplate reader (Bio-Rad iMark), shaker (ASOne RM-300), centrifuge (Eppendort ${ }^{\mathrm{R}}$, mikropipet dan tip $\left(\right.$ Eppendorf $\left.^{\circledR}\right)$, timbangan elektrik (ZJMZYM JM-B Analytical), aluminium foil, rak tabung reaksi, kertas saring, pH meter (Metrohm 691),

\section{Bahan}

Alpinia galanga L (Perkebunan MerapiHerbal Yogyakarta), Isolat E. coli (Kultur koleksi Lab. Mikrobiologi STIKES Nasional), Medium Luria-Bertani (LB) (Oxoid) (10.0 g Tryptone, $5.0 \mathrm{~g}$ - Yeast extract, $10.0 \mathrm{~g}-\mathrm{NaCl}$ dalam $1 \mathrm{~L}$ - air distillasi, diatur $\mathrm{pH} 7.3 \pm 0.2$ ). Nutrient Agar (NA) (Sigma-Aldrich): 5gPepton, $3 \mathrm{~g}$ - beef extract, $5 \mathrm{~g}-\mathrm{NaCl}, 15 \mathrm{~g}$ - agar. $\mathrm{pH}$ akhir: $7.3 \pm 0.2$. Medium Trypticase Soy Broth (TSB) (Oxoid), $0.6 \%$ Yeast Extract (TSBYE) (g/L): 30 g-Trypticase Soy Broth,6 gYeast Extract, dalam $1 \mathrm{~L}$ akuades, dengan $\mathrm{pH}$ akhir: $7.3 \pm 0.2$. Trypticase Soy Agar (TSA) dengan komposisi sama dengan TSB, ditambah $15-20 \mathrm{~g} / \mathrm{L}$ agar. crystal violet $0,1 \%$, etil alkohol 95: $20 \mathrm{ml}$, ammonium oksalat $0,8 \mathrm{~g}$, akuades $80 \mathrm{ml}$

\section{Tahapan Penelitian}

\section{Ekstraksi Alpinia galangal L.}

Alpinia galanga L (Lengkuas) yang digunakan dalam penelitian ini adalah jenis 
Lengkuas merah besar berumur $4-5$ bulan, Rimpang $A$. galanga $L$ yang masih segar sebanyak $1 \mathrm{~kg}$ diparut dan dikeringkan pada suhu $50^{\circ} \mathrm{C}$ selama 5 hari.

Setelah kering, $100 \mathrm{~g}$ larutan rimpang Lengkuas diekstrak dalam $500 \mathrm{~mL}$ etanol $70 \%$ selama 24 jam pada suhu kamar. Setelah disaring, filtrat dievaporasi dengan rotary evaporator $\left(40^{\circ} \mathrm{C}\right.$, vakum). Setelah kering ekstrak ditambah $10 \mathrm{~mL}$ etanol dan $20 \mathrm{~mL}$ heksana. Setelah dikocok, lapisan heksana yang mengandung lemak dibuang. Lapisan etanol dikeringkan sampai menjadi kristal. Ekstrak kering $(1 \mathrm{~g})$ dilarutkan dalam larutan etanol 1\% $(1: 100 ; \mathrm{w} / \mathrm{v})$, kemudian dibuat seri konsentrasi 10, 20, 30, 40 dan 50\% (Khairullah et al., 2020).

\section{Purifikasi isolat E. coli.}

Purifukasi Isolat E, coli dilakukan dengan teknik kultur koloni sel tunggal (AxlerDiPerte, 2017), koloni isolat bakteri diambil menggunakan ohse digoreskan pada permukaan media agar Mac Conkey dengan teknik goresan dalam cawan petri (streak plate), diinkubasi pada suhu $37^{\circ} \mathrm{C}$ selama 24 jam. Koloni yang tumbuh terpisah diambil dan dipindahkan ke medium Nutrient Agar miring sebagai biakan murni.

Karakterisasi kepekaan isolat terhadap berbagai macam antibiotika dilakukan dengan menggunakan Vitek 2 Compact System (Barenfanger et al, 1999), berdasarkan metode turbidimetri (dilusi) dengan satuan $\mathrm{ug} / \mathrm{mL}$ dan diinterpretasikan berdasarkan clinical and laboratory standar institute (CLSI) M100-S25 tahun 2015. (Palleroni, 2015).

Penyiapan biakan murni $P$. aeruginosa dilakukan untuk pengujian selanjutnya dengan membuat sub kultur cair dari masing-masing kultur, yaitu menginokulasikan ke $10 \mathrm{~mL}$ media Luria Bertani cair, diinkubasi pada suhu $37^{\circ} \mathrm{C}$, selama 24 jam.

\section{Uji Pengaruh Ekstrak Alpinia galanga L terhadap produksi Biofilm $E$. coli.}

Kultur E. coli pada media LB segar yang mengandung ekstrak Alpinia galanga $\mathrm{L}$ pada konsentrasi $0 \%$ (sebagai kontrol) 10\%, $20 \%, \quad 30 \%, \quad 40 \%$ dan $50 \%$, kemudian diinkubasi dalam $10 \mathrm{ml}$ media diperkaya TSBYE, pada suhu $37^{\circ} \mathrm{C}$ selama $24 \mathrm{jam}$. Tes produksi biofilm dilakukan dengan media Luria Bertani. Kultur semalam di TSBYE dipindahkan $(0,1 \mathrm{ml})$ ke $10 \mathrm{ml}$ Luria Bertani dan divortex.

Setelah divortex, 100 $\mu$ l dialihkan ke dalam delapan microtiter (Becton Dickinson Labware, Franklin Lakes, NJ), sebelumnya dibilas dengan $70 \%$ etanol dan udara kering. Setiap plate termasuk delapan sumur MWB tanpa E. coli sebagai kontrol. Kekeruhan sel dipantau menggunakan microtiter plate (BioRad, Richmond, Calif), dengan densitas optik $595 \mathrm{~nm}$ (OD595), kemudian diinkubasi selama 24 jam pada suhu $37^{\circ} \mathrm{C}$.

Setelah inkubasi, media telah dihilangkan dari sumuran, dan sumur microtiter plate dicuci lima kali dengan air suling steril untuk menghilangkan bakteri yang tidak terikat kuat (O’toole, 2011; Hassan et al., 2011).

Plate dikeringkan di udara selama 45 menit dan masing-masing dilakukuan pewarnaan dengan $150 \mu \mathrm{l}$ dari kristal violet $1 \%$ larutan dalam air selama 45 menit. Setelah pewarnaan, plate yang dicuci dengan air suling steril lima kali. Pada kondisi ini, biofilm yang terlihat sebagai cincin ungu yang terbentuk di sisi masing-masing dengan baik. Analisis kuantitatif produksi biofilm dilakukan dengan menambahkan $200 \mu \mathrm{l}$ dari $95 \%$ etanol ke dalam sumur. Seratus mikroliter dari masingmasing dipindahkan ke microtiter plate baru dan OD ungu kristal yang ada diukur pada 595 $\mathrm{nm}$ dengan microplate reader (Hassan et al., 2011; Wahyudi et al., 2019)

\section{Analisa Data}

Penghambatan produksi biofilm pada E. coli dilihat dari hasil uji produksi biofilm dengan metode Microtiter Plate Polivinil Kloridapada media Luria bertani yang telah ditambahkan ekstrak etanol pada masingmasing konsentrasi $0 \%, 10 \%, 20 \%, 30 \%, 40 \%$ dan $50 \%$. Hasil pengukuran produksi biofilm berupa besarnya nilai Optical Density ungu kristal yang ada diukur pada $595 \mathrm{~nm}$. Data dianalisis dengan one way anova dengan aplikasi SPSS Microsoft Window's, dan dilanjutkan dengan uji banding antar kelompok (posh hock test) sebelumnya dilakukan uji normalitas dan homogenitas.

\section{Hasil dan Pembahasan}

E. coli hasil purifikasi dari media Mac Conkey memiliki karakteristik koloni tipe mucoid (mengkilap) dengan pigmen warna 
merah, dan berukuran besar dengan diameter 2-3 mm. Hasil uji kepekaan E. coli terhadap beberapa antibiotic menunjukkan bahwa isolat E. coli telah resisten terhadap Amoxycillin, Clindamisin, Sulfamethaxazole, Trimethoprim, Cloramphenicol, Netilmycin, Kanamycin (Tabel 1).

Tabel 1. Uji kepekaan $E$. coli terhadap antibiotik

\begin{tabular}{clcc}
\hline No. & \multicolumn{1}{c}{ Antibiotik } & $(\mu \mathrm{g})$ & Hasil \\
\hline 1 & Amoxycillin & 10 & resisten \\
2 & Cefriaxone & 30 & sensitif \\
3 & Clindamisin & 5 & resisten \\
4 & Ciprofloxacine & 5 & sensitif \\
5 & Sulfamethaxazole & 100 & resisten \\
6 & Trimethoprim & 5 & resisten \\
7 & Meropenem & 30 & sensitif \\
8 & Imipenem & 30 & sensitif \\
9 & Amikacin & 300 & sensitif \\
10 & Cloramphenicol & 30 & resisten \\
11 & Gentamycin & 10 & sensitif \\
12 & Netilmycin & 15 & resisten \\
13 & Kanamycin & 15 & resisten \\
14 & Cefepime & 30 & sensitif \\
15 & Ofloxacin & 30 & sensitif \\
\hline
\end{tabular}

Hasil uji kepekaan E. coli terhadap antibiotic tersebut sejalan dengan beberapa penelitian sebelumnya yang menyatakan secara umum E. coli telah mengalami resisten dengan antibiotic amoxicillin, sulfametaoxazole, trimethoprim, dan kanamycin (Hilda, 2017; Poirel et al., 2018). Secara umum antibiotic amikacin, meropenem, imipenem, dan ciprofloxacin merupakan antibiotic yang masih memiliki kemampuan yang baik dalam mengatasi infeksi yang disebabkan E. coli (Tabel. 1), hal ini sejalan dengan hasil penelitian yang dilaporkan Nurmala et al., (2015), Yassin et al., (2017), dan Widianingsih \& de Jesus (2018).

Produksi biofilm E. coli ketika ditumbuhkan pada media LB yang telah di tambahkan ekstrak Alpinia galangal $\mathrm{L}$ terlihat mengalami penghambatan, semakin besar konsentrasi ekstrak yang ditambahkan ke dalam media maka semakin besar pula besarnya massa biofilm yang terhambat (Gambar 1).
Hasil uji statistika menunjukkan bahwa data optical density hasil pembentukan biofilm E. coli yang ditumbuhkan pada berbagai konsentrasi normal dan homogen, yang ditunjukkan dengan hasil uji Shapiro Wilk 0,263 (lebih dari 0,05). Uji one way anova yang telah dilakukan menunjukkan bahwa terdapat perbedaan signifikan antar konsentrasi, hal ini ditunjukkan dengan nilai signifikan uji one way anoya adalah 0,001 (minimal ada dua atau lebih konsentrasi yang memiliki perbedaan yang signifikan dalam menghambat pembentukan biofilm E. coli). Uji lanjut, perbedaan antar konsentrasi dilakukan dengan post hock tes, didapatkan hasil bahwa pada konsentrasi 30 merupakan konsentrasi terkecil yang berbeda signifikan dengan control negatif, sehingga bias dikatakan bahwa bahwa Ekstrak Alpinia galanga L mampu menghambat produksi biofilm E. coli pada konsentrasi 30\% (Gambar 1).

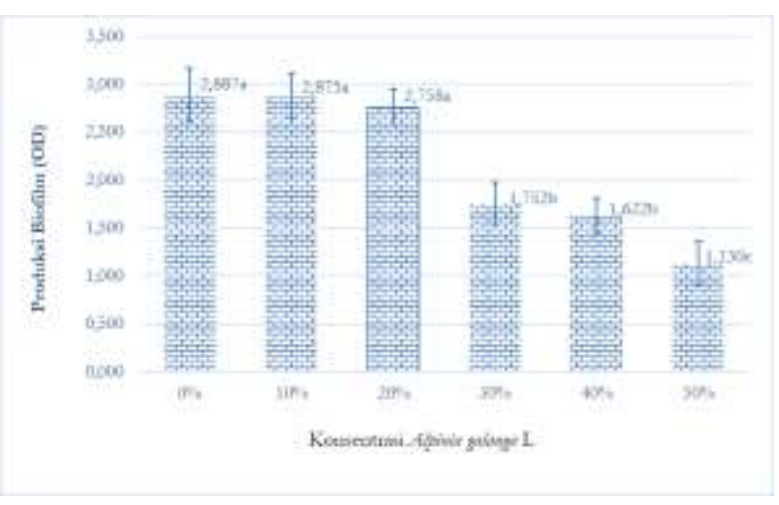

Gambar 1. Pengaruh Ekstrak Alpinia galanga L dalam menghambat produksi biofilm. (ket: Huruf yang sama menunjukkan tidak berbeda signifikan pada taraf 0,05 )

Konsentrasi 30\% memiliki kemampuan yang sama dengan konsentrasi $40 \%$ dalam menghambat biofilm E. coli. Konsentrasi 50\% merupakan konsentrasi yang memiliki kemampuan menghambat pembentukan biofilm paling besar, hasil penelitian ini menjadi acuan perdana dalam melakukan uji selanjutnya, ekstrak yang digunakan pada penelitian ini adalah esktrak kasar yang perlu dilakukan uji selanjutnya, fraksinasi dan purifikasi, agar bias semakin diketahui potensi yang terdapat dalam Alpinia galangal $\mathrm{L}$ ini dalam menghambat pembentukan biofilm pada E. coli. 
Jika dibandingkan dengan penelitian Wahyudi et al., 2011 ekstrak Alpinia galanga L telah mampu menghambat sistem quorum sensing pada Pseudomonas aeruginosa pada konsentrasi 8\%, perbedaan ini bisa terjadi karena jenis bakteri uji memang berbeda spesies, dan bahan herbal Alpinia galanga $\mathrm{L}$ yang digunakan memang diambil dari tempat yang berbeda.

Penghambatan biofilm bakteri dengan haban herbal ini menjadi peluang di banyak bidang untuk dikembangkan, terbentuknya biofilm dalam tubuh (manusia dan hewan) lebih banyak mengakhibatkan kerugian bagi kesehatan, penemuan senyawa-senyawa herbal yang mempu menghambat pembentukan biofilm ini diharapkan menjadi alternatif pencegahan maupun penyembuhan infeksi yang terjadi pada manusia maupun hewan.

\section{Kesimpulan}

Eksktrak Alpinia galangan L pada konsentrasi $30 \%$ mampu menghambat pembentukan biofilm Escherichia coli.

\section{Ucapan Terima Kasih}

Terima kasih kepada Lembaga Penelitian dan Pengabdian Masyarakat (LPPM) Sekolah Tinggi Ilmu Kesehatan Nasional yang telah mendanai Penelitian ini dengan nomor kontrak: (SK:037.1/LPPM/STIKESNAS/PEN$\mathrm{IN} / \mathrm{K} / \mathrm{VII} / 2020$

\section{Daftar Pustaka}

Abdelhamid, A. G., Esaam, A., \& Hazaa, M. M. (2018). Cell free preparations of probiotics exerted antibacterial and antibiofilm activities against multidrug resistant $\mathrm{E}$. coli. Saudi pharmacentical journal, 26(5), 603607.

Al-Shabib, N. A., Husain, F. M., Ahmad, I., Khan, M. S., Khan, R. A., \& Khan, J. M. (2017). Rutin inhibits mono and multispecies biofilm formation by foodborne drug resistant Escherichia coli and Staphylococcus aureus. Food Control, 79, 325-332.

Alvina, M. K. (2018). Efek Ekstrak Etanol Teh Hijau (Camellia sinensis var. assamica) sebagai Penghambat Pembentukan Biofilm Escherichia coli secara In Vitro (Doctoral dissertation, Universitas Brawijaya).
Axler-DiPerte G L., 2017. Modeling and Visualizing Bacterial Colony Purification Without the Use of Bacteria or Laboratory Equipment. J Microbiol Biol Educ. 18(2): 241-255.

Barenfanger, J., Drake, C. \& Kacich, G., 1999. Clinical and financial benefits of rapid bacterial identification and antimicrobial susceptibility testing. Journal of clinical microbiology, 37(5): 1415-1418.

Cepas, V., López, Y., Muñoz, E., Rolo, D., Ardanuy, C., Martí, S., ... \& Soto, S. M. (2019). Relationship between biofilm formation and antimicrobial resistance in gram-negative bacteria. Microbial Drug Resistance, 25(1), 72-79.

Chouni, A., \& Paul, S. (2018). A review on phytochemical and pharmacological potential of Alpinia galanga. Pharmacognosy Journal, 10(1).

Chouni, A., \& Paul, S. (2018). A review on phytochemical and pharmacological potential of Alpinia galanga. Pharmacognosy Journal, 10(1).

Fajrin, P.E. (2020). Uji Aktivitas Antibiofilm Ekstrak Air Daun Maman (Cleome Gynandra L.) Terbadap bakteri Escherichia Coli DAN Staphylococcus Aureus (Doctoral dissertation, Universitas Tadulako).

Hassan A, Javaid U, Fatima K, Maria O, Ali K, \& Muhammad I., 2011. Evaluation of different detection methods of biofilm formation in the clinical isolates., Department of Microbiology National University of Sciences and Technology, Islamabad, Army Medical College, Rawalpindi, Pakistan., Elsevier

Hilda, H. (2017). Pola Resistensi Bakteri Staphylococus Aureus, Escherichia Coli, Pseudomonas Aeruginosa Terhadap Berbagai Antibiotik. Husada Mabakam: Jurnal Kesehatan, 4(1), 11-17.

Jihan Kalishah, N. (2019). REesistensi Antimikroba Cefotaxime dan Ceftriaxone pada Escherichia coli yang dibasilkan oleh Pembentukan Biofilm (Doctoral dissertation, Universitas Airlangga).

Khairullah, A. R., Solikhah, T. I., Ansori, A. N. M., Fadholly, A., Ramandinianto, S. C., Ansharieta, R., ... \& Anshori, A. (2020). A Review of an Important Medicinal Plant: Alpinia galanga (L.) Willd. Systematic Reviens in Pharmacy, 11(10), 387-395. 
Moradigaravand, D., Palm, M., Farewell, A., Mustonen, V., Warringer, J., \& Parts, L. (2018). Prediction of antibiotic resistance in Escherichia coli from large-scale pangenome data. PLoS computational biology, 14(12), e1006258.

Mukti, A. (2017). Resistensi escherichia coli terhadap antibiotik dari daging ayam broiler di pasar rukoh (the antibiotic resitance escherichia coli in broiler meat at rukoh market). Jurnal Ilmiah Mahasiswa Veteriner, 1(3), 492-498.

Nadhiroh, S. (2019). Uji. Efektivitas Ekstrak Etanol Bawang Putih (Allium Sativum) Sebagai Pengahambat Pembentukan Biofilm Escherichia Coli Secara In Vitro (Doctoral dissertation, Universitas Brawijaya).

Nurmala, N., Virgiandhy, I. G. N., Andriani, A., \& Liana, D. F. (2015). Resistensi dan sensitivitas bakteri terhadap antibiotik di RSU dr. Soedarso Pontianak tahun 20112013. eJournal Kedokteran Indonesia.

O’Toole GA 2011., Microtiter dish biofilm formation assay. Jo Ve. 47:1-2.

Palleroni, N.J. 2015. Genus I. Pseudomonas Migula 1894. In Bergey's Manual of Systematic Bacteriology, $4^{\text {th }}$ edn, Vol. 2 The Proteobacteria, Part B, The Gammaproteobacteria.

Poirel, L., Madec, J. Y., Lupo, A., Schink, A. K., Kieffer, N., Nordmann, P., \& Schwarz, S. (2018). Antimicrobial resistance in Escherichia coli. Antimicrobial resistance in bacteria from livestock and companion animals, 289-316.

Prasetya, Y. A., Nisyak, K., \& Amanda, E. R. (2019). Aktivitas Antibakteri Nanoemulsi Minyak Lengkuas (Alpinia galanga L. Willd) dalam menghambat pertumbuhan Helicobacter pylori. Biotropika: Journal of Tropical Biology, 7(3), 136-142.

Putri, P. A. T. K. (2019). Efek Ekstrak Etanol Daun Kemangi (Ocimum sanctum) Sebagai Penghambat Pembentukan Biofilm Escherichia Coli Secara In Vitro (Doctoral dissertation, Universitas Brawijaya).

Rini, C. S., Rohmah, J., \& Widyaningrum, L. Y. (2018, September). The antibacterial activity test galanga (Alpinia galanga L) on the growth of becteria Bacillus subtilis and Escherichia coli. In IOP Conference Series: Materials Science and Engineering (Vol. 420, No. 1, p. 012142). IOP Publishing.
Sabir, N., Ikram, A., Zaman, G., Satti, L., Gardezi, A., Ahmed, A., \& Ahmed, P. (2017). Bacterial biofilm-based catheterassociated urinary tract infections: Causative pathogens and antibiotic resistance. American journal of infection control, 45(10), 1101-1105.

Safitri, R. D. (2019). Uji Efektivitas Flavonoid Ekstrak Buah Mabkota Dewa Phaleria macrocarpa) Terhadap Penghambatan Pembentukan Biofilm Pada Escherichia coli Secara In vitro (Doctoral dissertation, Universitas Brawijaya).

Sahputri, J., Lindarto, D., \& Ganie, R. A. (2018). Hubungan pembentukan biofilm oleh Bakteri Gram negatif dengan resistensi antibiotic pada wanita diabetes melitus tipe 2. Averrous: Jurnal Kedokteran dan Kesehatan Malikussaleh, 4(1), 50-61.

Singh, S., Singh, S. K., Chowdhury, I., \& Singh, R. (2017). Understanding the mechanism of bacterial biofilms resistance to antimicrobial agents. The open microbiology journal, 11, 53.

Sumampouw, O. J. (2018). Uji Sensitivitas Antibiotik Terhadap Bakteri Escherichia Coli Penyebab Diare Balita Di Kota Manado. The Sensitivity Test of Antibiotics to Escherichia coli was Caused The Diarbhea on Underfive Children in Manado City, 2(1), 104110.

Surgers, L., Boyd, A., Girard, P. M., Arlet, G., \& Decré, D. (2019). Biofilm formation by ESBL-producing strains of Escherichia coli and Klebsiella pneumoniae. International Journal of Medical Microbiology, 309(1), 13-18.

Viana, P. R. S., Leite, D. S., Mouchrek Filho, V. E., de Sousa, D. A., de Mattos Guaraldi, A. L., Alves, M. B., ... \& Sabbadini, P. S. (2020). Antimicrobial and anti-biofilm activities of Alpinia zerumbet (Pers.) BL Burtt \& RM Sm. essential oil against Corynebacterium ulcerans. Ciência e Natura, 42

Wahyudi, D, Soetarno, Pangastuti A, 2011, Penghambatan Quorum sensing Pseudomonas aeruginosa Oleh Ekstrak Alpinia galangal L (Tesis, Universitas Sebelas Maret, Surakarta).

Wahyudi, D. (2014). Uji Efektivitas Ekstrak Seledri (Apium graveolens L) Sebagai Penghambat Produksi Biofilm Pada Salmonella typhi. Biomedika, 7(2), 1-10.

Wahyudi, D., \& Silviani, Y. (2015). Penghambatan Produksi Eksoprptease dan Biofilm pada Pseudomonas aeruginosa Olek Ekstrak Apium graveolens L. Jurnal Kesehatan Kusuma Husada. 
Wahyudi, D., Aman, A. T., Handayani, N. S. N., \& Soetarto, E. S. (2019). Differences among clinical isolates of Pseudomonas aeruginosa in their capability of forming biofilms and their susceptibility to antibiotics. Biodiversitas Journal of Biological Diversity, 20(5).

Widianingsih, M., \& de Jesus, A. M. (2018). Isolasi Escherichia coli Dari Urine Pasien Infeksi Saluran Kemih Di Rumah Sakit Bhayangkara Kediri. Al-Kauniyah; Journal of Biology, 11(2), 99-108.

Yassin, A. K., Gong, J., Kelly, P., Lu, G., Guardabassi, L., Wei, L., ... \& Wang, C. (2017). Antimicrobial resistance in clinical Escherichia coli isolates from poultry and livestock, China. PloS one, 12(9), e0185326. 